\title{
Deletion polymorphism of the angiotensin converting enzyme gene predicts persistent proteinuria in Henoch-Schönlein purpura nephritis
}

Toshimasa Yoshioka, Ya-xin Xu, Hiroaki Yoshida, Hiroshi Shiraga, Takamura Muraki, Katsumi Ito

\begin{abstract}
Objective-To study the influence of deletion/insertion polymorphism in the 16th intron of the angiotensin converting enzyme (ACE) gene on clinical manifestations of Henoch-Schönlein purpura nephritis.
\end{abstract}

Study design-Cross sectional study. ACE gene polymorphism was determined in patients (4-15 years old at onset) with Henoch-Schönlein purpura nephritis $(n=40)$ and compared with that in patients with IgA nephropathy $(n=79)$.

Main outcome measures-ACE genotypes, systemic blood pressures, urine protein excretion rate, haematuria, creatinine clearance, serum ACE activities.

Results-The initial clinical manifestations of both Henoch-Schönlein purpura nephritis and IgA nephropathy were no different among homozygotes for insertion (II) and deletion (DD), and heterozygotes (ID) for the ACE gene. In patients with Henoch-Schönlein purpura nephritis, the incidence of moderate to heavy proteinuria at four and eight years after onset was more than five times higher in the DD genotype than in the II or ID genotypes. No such trend was seen in patients with IgA nephropathy. The number of patients with HenochSchönlein purpura nephritis in whom proteinuria resolved at four and eight years after onset was significantly lower in the DD genotype compared with the II genotype, whereas no differences were detected among the three different genotypes in patients with IgA nephropathy. Plasma ACE activities in patients with the DD genotype were significantly higher than in those with non-DD genotypes. Conclusions-The ACE DD genotype predicts persistent proteinuria in HenochSchönlein purpura nephritis. The proteinuria might be related to a defective angiotensin system which is genetically determined by the D/I polymorphism.

(Arch Dis Child 1998;79:394-399)

Keywords: chronic glomerulonephritis; IgA nephropathy; angiotensin converting enzyme activity; HenochSchönlein purpura nephritis

Henoch-Schönlein purpura nephritis is a common cause of chronic glomerulonephritis in children. ${ }^{1}$ Although most patients follow a benign clinical course, some patients exhibit persistent urinary abnormalities and progress to terminal renal failure. ${ }^{2-5}$ The mechanisms of the renal involvement in Henoch-Schönlein purpura and the chronicity of the renal abnormality have not been elucidated.

Renal histological changes in HenochSchönlein purpura nephritis share some similarities with those in IgA nephropathy, another common chronic glomerulonephritis in children. ${ }^{6-9}$ Recent studies in adults demonstrated a genetic association between deletion (D) and insertion (I) polymorphisms of the angiotensin converting enzyme (ACE) gene and chronic progression of $\operatorname{IgA}$ nephropathy. ${ }^{10-14} \mathrm{~A}$ high incidence of deletion polymorphism in the 16th intron of the gene has been seen in adult patients with IgA nephropathy who progressed to end stage renal failure. The same polymorphism is thought to be associated with the progression of other renal (for example, diabetic nephropathy) and nonrenal (for example, left ventricular hypertrophy) diseases. ${ }^{15-21}$ Although the exact mechanism of the gene polymorphism related disease progression remains unclear, a rise in ACE activity, and hence higher angiotensin II concentrations, has been implicated as a physiological consequence of the deletion. ${ }^{1422-28}$

Both experimental and clinical studies suggest that angiotensin II modulates glomerular permeability and selectivity. ${ }^{11} 1415$ Therefore, it is reasonable to assume that high local angiotensin II concentrations as a result of deletion polymorphism of the ACE gene is associated with proteinuria in chronic renal diseases. In our study, we evaluated the association of the ACE D/I gene polymorphism with clinical manifestations, particularly proteinuria, in patients with Henoch-Schönlein purpura nephritis. We also examined clinical manifestations according to ACE genotypes in patients with IgA nephropathy as a reference. The onset of both diseases was well defined in the children studied; in general, HenochSchönlein purpura nephritis was recognised early by non-renal symptoms, and IgA nephropathy was detected early by the Japanese mass urinary screening system, which is performed every six to 12 months in all school children. ${ }^{29}{ }^{30}$ This enabled comparisons of clinical manifestations at given periods of the disease among the three ACE genotypes in patients with Henoch-Schönlein purpura nephritis and IgA nephropathy. 


\section{Methods}

PATIENTS

A total of 186 patients with either HenochSchönlein purpura nephritis $(n=59)$ or IgA nephropathy $(\mathrm{n}=127)$ attended or admitted to the department of pediatric nephrology, Tokyo Women's Medical College between 1 November 1995 and 31 October 1996 were considered for our study. Forty patients with Henoch-Schönlein purpura nephritis and 79 patients with IgA nephropathy fulfilled the entrance criteria of our study; consent was obtained from all patients or guardians. The entrance criteria required the patient to be: (1) between 4 and 15 years of age at onset of the disease; (2) followed for at least two years after onset; and (3) monitored regularly by blood pressure measurement, determination of 24 hour urine protein excretion rate, and examination of red blood cell sedimentation in first voiding urine sample. Reasons for exclusion from the study for not meeting the entrance criteria were: (1) the age of onset was $<4$ or $>15$ years $(n=18)$; (2) the length of follow up was less than two years $(n=34)$; or (3) the patients' medical records were incomplete because they had been referred from other institutions $(n=17)$. (There was more than one reason in some patients.) All patients with IgA nephropathy were biopsied to confirm the diagnosis. The diagnosis of Henoch-Schönlein purpura nephritis was based on clinical symptoms (cutaneous, gastrointestinal, and joint symptoms associated with haematuria/ proteinuria). Thirty four patients with Henoch-Schönlein purpura nephritis underwent renal biopsy. None of the patients were treated with ACE inhibitors during or before the study. The study protocol had been approved by the institutional ethics committee for clinical investigation.

The profile of patients at onset of disease is given in table 1 . The average age at onset was slightly but significantly higher in patients with IgA nephropathy $(p<0.05)$. All patients in the study presented at the renal clinic at a relatively early stage (less than one year after onset) of the disease because of the regular mass screening for urinary abnormality performed in all Japanese school children and because of the typical clinical symptoms of HenochSchönlein purpura nephritis. Thirty six of the patients with Henoch-Schönlein purpura nephritis and 67 of the patients with $\operatorname{IgA}$ nephropathy were followed for four years from onset, and 20 patients with Henoch-Schönlein

Table 1 Profile of patients at onset

\begin{tabular}{lll}
\hline & HSPN & IgA nephropathy \\
\hline $\begin{array}{l}\text { Number of patients } \\
\text { Male/female }\end{array}$ & 40 & 79 \\
Age at onset (years) & $18 / 22$ & $41 / 38$ \\
$\quad$ Mean (SD) & $8.3(3.0)$ & $11.7(2.7)^{\star}$ \\
$\quad$ Range & $4-15$ & $4-15$ \\
Mode of initial presentation & 0 & 73 \\
$\quad$ Screening† & 40 & 5 \\
Nephritic/nephrotic symptoms & & \\
\hline
\end{tabular}

${ }^{\star} \mathrm{p}<0.05 v$ HSPN.

+Urinary abnormality detected at mass screening performed every 6 or 12 months in all Japanese school children.

HSPN, Henoch-Schönlein purpura nephritis. purpura nephritis and 31 patients with $\operatorname{IgA}$ nephropathy were followed for eight years. These subsets of patients were evaluated further to compare the time related changes of clinical presentations.

EXTRACTION OF GENOMIC DNA AND DETERMINATION OF THE ACE GENOTYPE BY PCR Genomic DNA was extracted from peripheral venous blood collected for routine blood tests. The genomic DNA was purified using a DNA isolation kit (Invitrogen, San Diego, California, USA), suspended in $10 \mathrm{mM}$ Tris- $\mathrm{HCl}, 1 \mathrm{mM}$ EDTA, $\mathrm{pH}$ 8.0, and DNA concentrations were measured spectrophotometrically at $260 \mathrm{~nm}$.

ACE genotypes were determined using the polymerase chain reaction (PCR) technique as reported previously. ${ }^{31}$ A $100 \mu$ reaction mixture contained $1 \mu \mathrm{g}$ genomic DNA, $2 \mu \mathrm{M}$ primers, $200 \mu \mathrm{M}$ each dATP, dGTP, dCTP, and dTTP, $1.5 \mathrm{mM} \quad \mathrm{MgCl}_{2}, 2.5 \mathrm{U}$ Taq DNA polymerase (Takara, Osaka, Japan), $50 \mathrm{mM} \mathrm{KCl}$, and $10 \mathrm{mM}$ Tris/HCl, pH 8.3. An optimised primer pair (sense: 5'-GCCCTGCAGGTGTCTGCAGGTGTCT3', and antisense: 5'-GGATGGCTCTCCCCGCCTTGTCTC-3') was used to amplify the D and I alleles, resulting in $319 \mathrm{bp}$ and $597 \mathrm{bp}$ amplicons, respectively. ${ }^{15}$ The thermocycling procedure (DNA Thermal Cycler 480, Perkin Elmer, Norwalk, Connecticut, USA) consisted of one cycle at $94^{\circ} \mathrm{C}$ for two minutes, followed by 35 cycles of denaturation at $94^{\circ} \mathrm{C}$ for 30 seconds, annealing at $56^{\circ} \mathrm{C}$ for 45 seconds, and extension at $72^{\circ} \mathrm{C}$ for two minutes; with a final extension at $72^{\circ} \mathrm{C}$ for seven minutes. The PCR product was visualised with ethidium bromide staining after electrophoresis on $2 \%$ agarose gels.

Because the $\mathrm{D}$ allele in heterozygous samples is amplified preferentially, the ID genotype can be mistyped as the DD genotype. ${ }^{15}$ Thus, each sample found to have the DD genotype by the original primers was subjected to a repeated PCR amplification and to another PCR amplification using an insertion specific primer pair (sense: 5'-TGGGACCACAGCGCCCGCCACTAC-3' and antisense: 5'-TCGCCAGCCCTCCCATGCCCATAA-3') under identical PCR conditions except for an annealing temperature of $67^{\circ} \mathrm{C}$. The reaction yielded a $335 \mathrm{bp}$ amplicon in the presence of an I allele, and no products in samples homozygous for DD.

MEASUREMENT OF PLASMA ACE ACTIVITY Plasma ACE activity was determined in some patients with normal creatinine clearance $\left(>80 \mathrm{ml} /\right.$ minute $/ 1.73 \mathrm{~m}^{2}$ ). Blood samples were collected after at least 30 minutes of rest. Plasma was separated immediately and stored at $-80^{\circ} \mathrm{C}$ until assayed for ACE activity. The ACE activity was determined by colorimetric measurement of the quinoneimine dye produced from the substrate p-hydroxyhippurylL-histidyl-L-leucine by the action of ACE as reported previously. ${ }^{32}$ 
Table 2 Comparison of clinical presentations between ACE DD and non-DD genotypes in patients with Henoch-Schönlein purpura nephritis (HSPN) and IgA nephropathy

\begin{tabular}{|c|c|c|c|c|c|c|}
\hline & \multicolumn{3}{|c|}{$\operatorname{HSPN}(n=40)$} & \multicolumn{3}{|c|}{ IgA nephropathy $(n=79)$} \\
\hline & $I I$ & $I D$ & $D D$ & $I I$ & $I D$ & $D D$ \\
\hline Number of patients & 17 & 15 & 8 & 33 & 35 & 11 \\
\hline Follow up (years) & $7.8(3.5)$ & $8.6(5.4)$ & $7.8(3.0)$ & $7.0(3.2)$ & $6.9(3.8)$ & $9.1(3.6)$ \\
\hline \multicolumn{7}{|c|}{ Haematuria (number of patients with $>1+$ by dipsticks) } \\
\hline Initial & 17 & 15 & 8 & 33 & 35 & 11 \\
\hline Final (number/total ${ }^{\star}$ ) & $4 / 17$ & $7 / 13$ & $4 / 7$ & $24 / 33$ & $27 / 34$ & $6 / 11$ \\
\hline \multicolumn{7}{|l|}{ Urine protein excretion rate $\left(\mathrm{mg} / \mathrm{m}^{2} /\right.$ day $)$} \\
\hline Initial & $1784(2320)$ & $1790(1588)$ & $1911(1183)$ & $563(549)$ & $526(457)$ & $723(747)$ \\
\hline Final & $129(332)$ & $311(537)$ & $520(436)$ & $300(372)$ & $292(524)$ & $190(273)$ \\
\hline \multicolumn{7}{|l|}{ Blood pressure $(\mathrm{mm} \mathrm{Hg})$} \\
\hline Initial systolic & $104(12)$ & $104(6)$ & $112(10)$ & $110(11)$ & $112(14)$ & $113(16)$ \\
\hline Initial diastolic & $54(11)$ & $55(8)$ & $58(8)$ & $57(12)$ & $59(9)$ & $65(8)$ \\
\hline Final systolic & $107(15)$ & $104(10)$ & $105(9)$ & $112(10)$ & $112(10)$ & $113(16)$ \\
\hline Final diastolic & $53(9)$ & $56(13)$ & $52(5)$ & $63(9)$ & $60(10)$ & $64(12)$ \\
\hline \multicolumn{7}{|l|}{ Creatinine clearance $\left(\mathrm{ml} / \mathrm{min} / 1.73 \mathrm{~m}^{2}\right)$} \\
\hline Final & $105(18)$ & $86(40)$ & $93(41)$ & $102(22)$ & $110(18)$ & $109(10)$ \\
\hline \multicolumn{7}{|l|}{ Degree of glomerular crescent at the first } \\
\hline biopsy $(\%) \dagger$ & $25.3(17.3)$ & $29.4(18.8)$ & $26.2(30.9)$ & ND & ND & $\mathrm{ND}$ \\
\hline \multicolumn{7}{|l|}{ Treatment $\ddagger$} \\
\hline Glucocorticoids & 6 & 5 & 3 & 14 & 14 & 3 \\
\hline Anticoagulants & 9 & 12 & 7 & 28 & 32 & 10 \\
\hline Plasmapheresis & 7 & 7 & 6 & 2 & 3 & 1 \\
\hline
\end{tabular}

Values in parentheses are SD.

Kruskal-Wallis test showed significant difference of final urine protein excretion rate among HSPN. No significant differences were observed among other clinical parameters in both HSPN and IgA nephropathy patients.

*Patients progressed to chronic renal failure (creatinine clearance $<50 \mathrm{ml} / \mathrm{min} / 1.73 \mathrm{~m}^{2}$ ) were excluded.

†Percentage of glomeruli with crescent in a section of biopsy specimen.

$¥$ Methods overlapped in some patients.

$\mathrm{ND}$, not determined.

STATISTICS

Data are expressed as means and standard deviation (SD) unless otherwise specified. One way ANOVA followed by Bonferroni/Dunn corrections were performed for continuous data and the Kruskal-Wallis rank test was used where applicable. ${ }^{33}$ The $\chi^{2}$ test was used to compare genotype frequencies for various clinical parameters including incidence of proteinuria and treatments. ${ }^{34}$ Significance was defined as $\mathrm{p}<0.05$.

\section{Results}

CLINICAL PRESENTATIONS OF HENOCH-SCHÖNLEIN PURPURA NEPHRITIS AND IgA NEPHROPATHY IN DIFFERENT ACE GENOTYPES

Table 2 summarises the clinical presentations of patients with Henoch-Schönlein purpura nephritis and $\operatorname{IgA}$ nephropathy according to ACE genotype. The allele frequency of deletion was 0.388 for patients with HenochSchönlein purpura nephritis and 0.361 for patients with IgA nephropathy. The frequency of the DD genotype in patients with HenochSchönlein purpura nephritis was significantly higher than that seen patients with IgA nephropathy and the Japanese population as a whole ( $12 \%$ in both adults and children)..$^{35}$ The age of onset (not shown in the table) and average length of follow up were not different among the three genotypes. Clinical symptoms (haematuria and blood pressure) and creatinine clearance at onset were not significantly different among the three genotypes, both for patients with Henoch-Schönlein purpura nephritis and those with IgA nephropathy. The degrees of glomerular crescent formation in the initial biopsies from patients with HenochSchönlein purpura nephritis were not significantly different among three genotypes. There were no differences in the distribution of treatment modalities. In patients with Henoch-
Schönlein purpura nephritis, chronic renal failure (creatinine clearance $<50 \mathrm{ml} /$ minute/ $1.73 \mathrm{~m}^{2}$ ) was seen in one patient with the DD genotype and two patients with the ID genotype; it was also seen in one patient with IgA nephropathy and the ID genotype. At the final follow up, patients with HenochSchönlein purpura nephritis and the DD genotype but not those with IgA nephropathy had a higher degree of proteinuria. The data showed large standard deviations, which might be affected by the differences in the lengths of follow up; therefore, further analysis was performed in patients who had been followed for identical lengths of time.

Table 3 compares the incidence of proteinuria at onset, four years, and eight years after onset in patients with Henoch-Schönlein purpura nephritis and IgA nephropathy with different ACE genotypes. When patients with moderate to severe proteinuria were compared, 28 of 40 and 35 of 79 patients with Henoch-Schönlein purpura nephritis and IgA nephropathy, respectively, had urine protein excretion rate greater than $500 \mathrm{mg} / \mathrm{m}^{2} /$ day at onset. No significant differences in the incidence of proteinuria at onset were seen among the three genotypes in the two sets of patients. In patients with Henoch-Schönlein purpura nephritis, the incidence of moderate to heavy proteinuria in the DD genotype remained high at four and eight years after onset (four of seven and three of four patients, respectively) but the incidence was significantly lower in non-DD genotypes (two of 29 and two of 16, respectively). In IgA nephropathy patients, the DD genotype was not associated with a higher incidence of moderate to severe proteinuria during the follow up period. When the incidence of patients with no proteinuria (urine protein excretion rate less than $100 \mathrm{mg} / \mathrm{m}^{2} /$ day) at onset were compared, there were no differences 
Table 3 Incidence of proteinuria in patients with Henoch-Schönlein purpura nephritis (HSPN) and IgA nephropathy with different ACE genotypes

\begin{tabular}{|c|c|c|c|c|c|c|}
\hline & \multicolumn{3}{|l|}{$H S P N$} & \multicolumn{3}{|c|}{ IgA nephropathy } \\
\hline & II & $I D$ & $D D$ & II & $I D$ & $D D$ \\
\hline \multicolumn{7}{|c|}{ Patients with moderate to heavy proteinuria ( $\geqslant 500 \mathrm{mg} / \mathrm{m}^{2} /$ day) } \\
\hline \multicolumn{7}{|l|}{ At onset } \\
\hline Number/total number (\%) & $9 / 17(55)$ & $12 / 15(80)$ & $7 / 8(88)$ & $15 / 33(45)$ & $15 / 35(43)$ & $5 / 11(45)$ \\
\hline $\mathrm{p}$ values $v \mathrm{DD}\left(\chi^{2}\right.$ test $)$ & 0.073 & 0.651 & NA & 1.000 & 0.880 & NA \\
\hline \multicolumn{7}{|l|}{4 years after onset } \\
\hline Number/total number (\%) & $1 / 17(6)$ & $1 / 12(8)$ & 4/7 (57) & $6 / 26(23)$ & $6 / 32(19)$ & $4 / 9(44)$ \\
\hline $\mathrm{p}$ values $v \mathrm{DD}\left(\chi^{2}\right.$ test $)$ & 0.005 & 0.019 & NA & 0.221 & 0.113 & NA \\
\hline \multicolumn{7}{|l|}{8 years after onset } \\
\hline Number/total number (\%) & $1 / 9(11)$ & $1 / 7(14)$ & $3 / 4(75)$ & $4 / 12(33)$ & $3 / 12(25)$ & $2 / 7(29)$ \\
\hline $\mathrm{p}$ values $v \mathrm{DD}\left(\chi^{2}\right.$ test $)$ & 0.021 & 0.044 & NA & 0.829 & 0.864 & NA \\
\hline \multicolumn{7}{|c|}{ Patients with no proteinuria $\left(<100 \mathrm{mg} / \mathrm{m}^{2} /\right.$ day $)$} \\
\hline \multicolumn{7}{|c|}{ At onset } \\
\hline Number/total number (\%) & $5 / 17(35)$ & $3 / 15(20)$ & $0 / 8(0)$ & $6 / 33(18)$ & $4 / 35(11)$ & $1 / 11(0.1)$ \\
\hline $\mathrm{p}$ values $v \mathrm{DD}\left(\chi^{2}\right.$ test $)$ & 0.086 & 0.175 & NA & 0.784 & 0.400 & 0.784 \\
\hline \multicolumn{7}{|l|}{4 years after onset } \\
\hline Number/total number (\%) & $13 / 17(76)$ & $7 / 12(58)$ & $1 / 7(14)$ & $8 / 26(31)$ & $13 / 32(41)$ & $2 / 9(22)$ \\
\hline $\mathrm{p}$ values $v \mathrm{DD}\left(\chi^{2}\right.$ test $)$ & 0.005 & 0.060 & NA & 0.625 & 0.311 & NA \\
\hline \multicolumn{7}{|l|}{8 years after onset } \\
\hline Number/total number (\%) & $7 / 9(78)$ & $4 / 7(57)$ & $0 / 4(0)$ & $5 / 12(42)$ & $6 / 12(50)$ & $3 / 7(43)$ \\
\hline $\mathrm{p}$ values $v \mathrm{DD}\left(\chi^{2}\right.$ test $)$ & 0.009 & 0.058 & NA & 0.960 & 0.764 & NA \\
\hline \multicolumn{7}{|l|}{ Mean (SD) urine protein excretion } \\
\hline \multicolumn{7}{|c|}{ Rate $\left(\mathrm{mg} / \mathrm{m}^{2} /\right.$ day) } \\
\hline 4 years after onset & $129(289)$ & $230(349)$ & $743(735)$ & $328(300)$ & $251(346)$ & $403(346)$ \\
\hline $\mathrm{p}$ values $v \mathrm{DD}$ (ANOVA) & 0.003 & 0.050 & NA & 0.426 & 0.507 & NA \\
\hline 8 years after onset & $108(265)$ & $168(228)$ & $696(483)$ & $551(799)$ & $162(209)$ & $263(283)$ \\
\hline $\mathrm{p}$ values $v$ DD (ANOVA) & 0.016 & 0.013 & NA & 0.216 & 0.163 & NA \\
\hline
\end{tabular}

Data at onset were derived from all patients enrolled, and those at 4 and 8 years after onset were derived from patients who were followed for the respective periods.

NA, not applicable.

among the three genotypes of ACE in both patients with Henoch-Schönlein purpura nephritis and those with IgA nephropathy. In patients with Henoch-Schönlein purpura nephritis, the proportion of those who were proteinuria free increased during the follow up period in the II and ID genotypes, while the proportion in the DD genotype remained low. In the non-DD genotypes, 20 of 29 and 11 of 16 patients were proteinuria free at four and eight years after onset, respectively, whereas in the DD genotype, only one of seven and none of four were proteinuria free at four and eight years after onset, respectively $(p<0.05)$. In patients with IgA nephropathy, we observed no statistical differences in the proportion of proteinuria free patients among the three genotypes throughout the eight years of follow up. The average urine protein excretion rates at follow up are also presented in table 3 and were similar among the three genotypes. In patients with Henoch-Schönlein purpura nephritis, the urine protein excretion rates in the $\mathrm{DD}$ genotype remained significantly higher throughout the follow up period compared with the II or ID genotype. No such genotypic differences were observed in IgA nephropathy. Other clinical manifestations, including systolic and diastolic blood pressures, degree of haematuria, and creatinine clearance, were no different among the three genotypes for both patients with Henoch-Schönlein purpura nephritis and those with IgA nephropathy.

PLASMA ACE ACTIVITIES

Plasma ACE activity was high in children with the DD genotype (fig 1), and there was a significant difference in ACE activity between the DD and II genotypes. The average ACE activity in the ID genotype was intermediate between those for the DD and II genotypes.

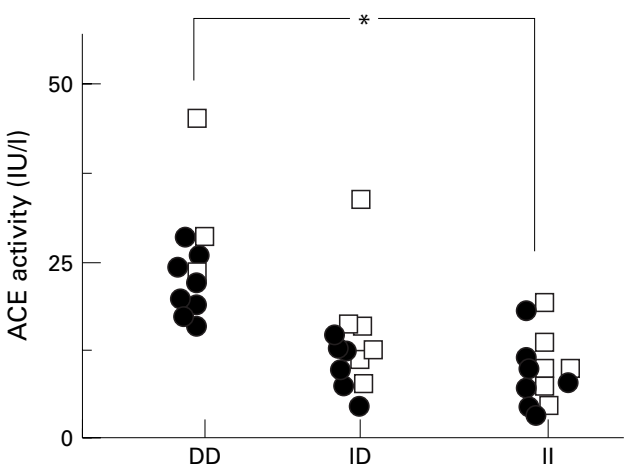

Figure 1 Plasma ACE activity in patients with Henoch-Schönlein purpura nephritis and IgA nephropathy. The plasma ACE activities were determined in patients with a normal glomerular filtration rate (creatinine clearance $>80 \mathrm{ml} /$ minute $1.73 \mathrm{~m}^{2}$ ) and not treated with $A C E$ inhibitors. Open squares and closed circles represent Henoch-Schönlein purpura nephritis and IgA nephropathy, respectively. ${ }^{*}$ Significant difference $(p<0.05)$.

Although there were outlying values in one each of the DD and the ID genotypes, we could not identify a reason for raised ACE activity in these patients.

\section{Discussion}

Our study examined the association between ACE polymorphism and clinical presentations of childhood Henoch-Schönlein purpura nephritis. Recent studies showed that D/I polymorphism of the ACE gene is associated with progression of IgA nephropathy and other renal diseases. ${ }^{10-141617}$ Because HenochSchönlein purpura nephritis shares some histological similarities with IgA nephropathy, which is another common childhood chronic glomerulonephritis, we compared patients with the two conditions. A characteristic of our study was disease onset (initial appearance of urinary abnormalities) and it was well defined 
in both Henoch-Schönlein purpura nephritis and IgA nephropathy. In contrast to adults with chronic glomerulonephritis, in whom onset of urinary abnormalities cannot be defined, all our patients presented within one year of onset because of the local mass screening system. This enabled us to evaluate time related changes in clinical manifestations in association with the ACE genotype of each patient.

In this study, a fifth of the patients with Henoch-Schönlein purpura nephritis had the DD genotype of the ACE gene. This frequency was higher than that seen in the general Japanese population, ${ }^{35}{ }^{36}$ and was also higher than that seen in our patients with $\operatorname{IgA}$ nephropathy. However, this might not be the true frequency in Henoch-Schönlein purpura because we studied only nephrotic/nephritic patients. Further studies are required to investigate the genotypes in all patients with Henoch-Schönlein purpura, to determine if the DD genotype is associated with nephritis.

The important finding of our study was the high incidence of persistent proteinuria in patients with Henoch-Schönlein purpura nephritis and the DD genotype. The incidence of proteinuria (urine protein excretion rate higher than $500 \mathrm{mg} / \mathrm{m}^{2} /$ day) at four to eight years after onset in patients with Henoch-Schönlein purpura nephritis and the DD genotype was more than five times higher than that in patients with the II genotype. The incidence in the ID genotype was intermediate between those in the DD and II genotypes. Our results also showed that proteinuria resolved less frequently in patients with the DD genotype than in those with non-DD genotypes. These findings indicate that the presence of the $\mathrm{D}$ allele is associated with persistence, and to some extent, the severity of proteinuria in children with HenochSchönlein purpura nephritis.

In contrast to Henoch-Schönlein purpura nephritis, we demonstrated no association between the ACE D/I polymorphism and proteinuria in patients with IgA nephropathy. Our results in IgA nephropathy were not consistent with those of previous studies in adults, which reported a relation between ACE D/I polymorphism and severity of proteinuria. ${ }^{10-12} 14 \mathrm{We}$ cannot define the exact reasons for the discrepancy between Henoch-Schönlein purpura nephritis and IgA nephropathy in our study as well as that between childhood and adult IgA nephropathy. Compared with previous studies in adults, we studied IgA nephropathy at an earlier stage of the disease (from onset to an average of approximately eight years after onset). Because the physiological effects of gene polymorphism appear to be present already at onset, other factors might mask the genetic influence of the deletion polymorphism in young patients with IgA nephropathy. In adult IgA nephropathy and diabetic nephropathy, the DD genotype predicts a greater risk of progressive renal failure. ${ }^{10-14} 1617 \mathrm{~A}$ decline in renal function takes place over 15 to 20 years in these chronic glomerular diseases. ${ }^{1-12} 37 \mathrm{Be}-$ cause most of our patients were followed for less than 10 years, conclusive data for the genomic influence on the progression of glomerulopathy can only be obtained in the future. Our present results suggest that the effect of ACE gene polymorphism must be evaluated not only by the specific disease but also by the stage of the disease.

The modalities of treatment might influence the outcome of both Henoch-Schönlein purpura nephritis and IgA nephropathy. Although none of the patients in our study received ACE inhibitors, they were treated with other regimens, including short term glucocorticoids (initial dose of $1 \mathrm{mg} / \mathrm{kg} / \mathrm{day}$, then tapered to withdrawal in about one year), anticoagulants (short term intravenous heparin followed by oral warfarin and/or dipyridamole), or plasmapheresis (three times a week for two to three weeks followed by a less frequent repeat for a total of 12 to 24 times) (table 2). Chi-square analysis revealed that none of the modalities were related to the outcome of proteinuria at four and eight years after onset (data not shown). The modalities of treatment were distributed equally among the three genotypes (table 2). We cannot determine from our data whether treatment prevented end stage renal disease because the number who progressed to end stage renal disease was too small (four among 119 patients) for meaningful analysis. Thus, more studies are required to analyse the effect of treatment on clinical outcome in different genotypes, and any effect of preventing end stage renal disease.

Patients with the DD genotype showed a significant rise in serum ACE activity, which has already been demonstrated in adults ${ }^{12} 2225$ and in children. ${ }^{36}$ Thus, patients with the DD genotype might have raised ACE activity and an abnormal regulation of the reninangiotensin system at the onset of disease. Our previous study in animals and recent studies in humans demonstrated a modulation of glomerular permeability and selectivity by the renin-angiotensin system. ${ }^{26} 3839$ The altered local angiotensin activity superimposed on the pathophysiological conditions induced by Henoch-Schönlein purpura nephritis might have resulted in persistent proteinuria. As stated earlier, a lack of association between proteinuria and the DD genotype in IgA nephropathy does not negate a possible contribution of angiotensin in its pathophysiology. Studies in adults with IgA nephropathy have shown a greater sensitivity to the antiproteinuric effect of ACE inhibitors in patients with the DD genotype. Similar trials in children will provide more insight into angiotensin dependent proteinuria in childhood onset Henoch-Schönlein purpura nephritis and IgA nephropathy, although prognosis of the persistent proteinuria in each disease needs to be determined first to evaluate the risk/benefits of treatment.

Our study has demonstrated a strong association between persistent proteinuria in childhood Henoch-Schönlein purpura nephritis and the deletion polymorphism of the ACE gene. Our findings suggest that the physiological effect of the polymorphism is already present in childhood, and might modify the clinical manifestation of Henoch-Schönlein purpura nephritis. The long term consequences of per- 
sistent proteinuria in patients with childhood Henoch-Schönlein purpura nephritis and the deletion genotype, as well as the gene effect of ACE polymorphism on childhood onset IgA nephropathy require further studies.

Part of this work was presented at the annual meeting of the American Society of Nephrology, 1996 (F Am Soc Nephrol 1996;7:1346).

This work was supported in part by the Grant-in-Aid for General Scientific Research (Nos 6671157 and 8671307) from General Scientific Research (Nos 667157 and 8671307 ) from the Japanese Ministry of Education, Science, Sports and Japan Private School Promotion Foundation.

1 Meadow SR. Schönlein-Henoch syndrome. In: Edelman $\mathrm{CM}$ Jr, ed. Pediatric kidney disease, Vol 2. Boston: Little CM Jr, ed. Pediatric kid

2 Koskimies O, Mir S, Rapola J, Vilska J. Henoch-Schoaelein nephritis: long-term prognosis of unselected patients. Arch nephritis: long-term prog

3 Mota-Hernandez F, Valbuena-Pa R, Gordillo-Paniagua G. Long-term prognosis of anaphylactoid purpura nephropathy. Pediatrician 1975;4:452-9.

4 Stewart M, Savage JM, Bell B, McCord B. Long-term renal prognosis of Henoch-Schoaelein purpura in an unselected childhood population. Eur F Pediatr 1988;147:113-15.

5 Goldstein AR, White RHR, Akuse R, Chantler C. Long-term follow-up of childhood Henoch-Schoanlein nephritis. Lancet 1992;339:280-2.

6 Galla JH. IgA nephropathy. Kidney Int 1995;47:377-87.

7 Julian BA, Waldo FB, Rifai A, Mestecky J. IgA nephropathy, the most common glomerulonephritis worldwide. A neglected disease in the United States? Am F Med 1988;84: 129-32.

8 Silverstein DM, Greifer I, Folkert V, Bennett B, Corey HE, Spitzer A. Sequential occurrence of IgA nephropathy and Henoch-Schönlein purpura: support for common pathogenesis. Pediatr Nephrol 1994;8:752-3.

9 Meadow SR, Scott DG. Berger disease: Henoch-Schönlein syndrome without the rash. F Pediatr 1985;106:27-32.

10 Harden PN, Geddes C, Rowe PA, et al. Polymorphisms in angiotensin-converting-enzyme gene and progression of IgA nephropathy. Lancet 1995;345:1540-2.

11 Yoshida H, Mitarai T, Kawamura T, et al. Role of the deletion polymorphism of the angiotensin-converting enzyme gene in the progression and therapeutic responsiveness of IgA nephropathy. $尹$ Clin Invest 1995;96:2162-9.

12 Yorioka T, Suehiro T, Yasuoka N, Hashimoto K, Kawada M. Polymorphism of the angiotensin-converting enzyme gene and clinical aspects of IgA nephropathy. Clin Nephrol 1995;44:80-5.

13 Gaciong ZA, Religa P, Placha G, Rell K, Paczek L. ACE genotype and progression of IgA nephropathy. Lancet genotype and

14 Hunley TE, Julian BA, Phillips JJ III, et al. Angiotensin converting enzyme gene polymorphism: potential silencer motif and impact on progression in IgA nephropathy. Kidney Int 1996;49:571-7.

15 Lindpaintner K, Pfeffer MA, Kreutz R, et al. A prospective evaluation of an angiotensin-converting-enzyme gene polymorphism and the risk of ischemic heart disease. $N$ Engl $\mathscr{f}$ Med 1995;332:706-11.

16 Marre M, Jeunemaitre X, Gallois Y, et al. Contribution of genetic polymorphism in the renin-angiotensin system to the development of renal complication in insulindependent diabetes. $\mathcal{F}$ Clin Invest 1997;43:1585-95.

17 Doria A, Warram JH, Krolewski AS. Genetic predisposition to diabetic nephropathy evidence for a role of the angiotensin I-converting enzyme gene. Diabetes 1994;43: $690-5$.
18 Schunkert H, Hense HW, Holmer SR, et al. Association between a deletion polymorphism of the angiotensinconverting enzyme gene and left ventricular hypertrophy. $N$ Engl f Med 1994;330:1634-8.

19 Cambien F, Poirier O, Lecerf L, et al. Deletion polymorphism in the gene for angiotensin-converting enzyme is a potent risk factor for myocardial infarction. Nature 1992;359:641-4.

20 Raynolds MV, Bristow MR, Bush EW, et al. Angiotensinconverting enzyme DD genotype on patients with ischaemic or idiopathic dilated cardiomyopathy. Lancet 1993;342: 1073-5.

21 Marian AJ, Yu QT, Workman R, Greve G, Roberts R. Angiotensin-converting enzyme polymorphism in hyperrophic cardiomyopathy and sudden cardiac death. Lancet 1993;342:1085-6.

22 Rigat B, Hubert C, Alhenc-Gelas F, Cambien F, Corvol P, Soubrier F. An insertion/deletion polymorphism in the angiotensin I-converting enzyme gene accounting for half the variance of serum enzyme levels. F Clin Invest 1990;86: 1343-6.

23 Wolf G, Neilson EG. Angiotensin II as a renal growth factor. f Am Soc Nephrol 1993;3:1531-40.

24 Costerousse O, Allegrini J, Lopez M, Alhenc-Gelas F. Angiotensin I-converting enzyme in human circulating mononuclear cells: genetic polymorphism of expression in T-lymphocytes. Biochem F 1993;290:33-40.

25 Tiret L, Rigat B, Visvikis S, et al. Evidence, from combined segregation and linkage analysis, that a variant of the angiotensin I-converting enzyme (ACE) gene controls plasma ACE levels. Am f Hum Genet 1992;51:197-205.

26 Yoshioka T, Mitarai T, Kon V, Deen WM, Rennke HG, Ichikawa I. Role for angiotensin II in an overt functional proteinuria. Kidney Int 1986;30:538-45.

27 Kojima S, Inenaga $\mathrm{T}$, Matsuoka $\mathrm{H}$, et al. The association between salt sensitivity of blood pressure and some polymorphic factors. $\mathcal{F}$ Hypertens $1994 ; \mathbf{1 2}: 797-801$.

28 Ueda S, Elliott HL, Morton JJ, Connell JMC. Enhanced presser response to angiotensin I in normotensive men with the deletion genotype (DD) for angiotensin-converting enzyme. Hypertension 1995;25:1266-9.

29 Kitagawa T. Lessons learned from the Japanese nephritis screening study. Pediatr Nephrol 1998;2:256-63.

30 Sakai T, Kitagawa T. Screening system for asymptomatic renal disease in children in Japan. Acta Paediatr $7 p n$ 1990;32:677-81

31 Rigat B, Hubert C, Corvol P, Soubrier F. PCR detection of the insertion/deletion polymorphism of the human angiotensin-converting enzyme gene (DCP1) (dipeptidyl carboxypeptidase 1). Nucleic Acids Res 1992;20:1433.

32 Kasahara Y, Ashihara Y. Colorimetry of angiotensin-I converting enzyme activity in serum. Clin Chem 1981;27: $1922-5$.

33 Daniel WW. Biostatistics: a foundation for analysis in the health science, 4th ed. New York: Wiley, 1987.

34 Wallenstein S, Zucker CL, Fleiss J. Some statistical methods useful in circulation research. Circ Res 1980;47:1-9.

35 Nomura H, Koni I, Michishita Y, Morise T, Takeda R. Angiotensin-converting enzyme gene polymorphism in haemodialysis patients. Lancet 1994;343:482-3.

36 Yamamoto K, Kataoka S, Hashimoto N, et al. Polymorphism of angiotensin I converting enzyme in Japanese chilphism of angiotensin I converting enzym

37 Yoshikawa N, Ito H, Nakamura H. IgA nephropathy in children from Japan. Child Nephrol Urol 1989;9:191-9.

38 Kitamura $\mathrm{H}$, Moriyama $\mathrm{T}$, Izumi $\mathrm{M}$, et al. Angiotensin I-converting enzyme insertion/deletion polymorphism: potential significance in nephropathy. Kidney Int 1996; 49(suppl 55):S101-3.

39 Hollenberg NK, Raij L. Angiotensin-converting enzyme inhibition and renal protection. An assessment of implications for therapy. Arch Intern Med 1993;153:2426-35. 